\title{
Factors governing the growth rate of roach Rutilus, rutilus (L.) in pre-alpine Lake Sarnen
}

\author{
Dedicated to Wolfgang Geiger \\ By Rudolf Müller and Hans Jürg Meng
}

Manuscript received on 5 May 1986

\begin{abstract}
Most of the mesotrophic to eutrophic lakes in central Europe have been showing signs of oligotrophication during recent years. The question as to how the fish populations would react to this new situation was investigated looking at the growth rate of roach Rutilus rutilus (L.) of Lake Sarnen, central Switzerland. The water temperature sum as day-degrees over 12 to $13^{\circ} \mathrm{C}$ for the months of June to October was found to be the predominant factor governing the marked year-to-year fluctuations of the growth rate. Contrary to expectation, the decreasing trophic state of the lake has not yet manifested itself noticeably in the growth rate.
\end{abstract}

\section{Introduction}

The individual growth rate of fish in lakes is determined primarily by food abundance and climatic factors, mainly temperature. Food production in lakes largely depends on primary production or trophic state in terms of total phosphorus concentration and relates to individual growth through fish population density. Furthermore, the exploitation rate has been demonstrated to influence fish growth rates [11]. The phenomenon of increasing growth rates associated with progressing lake eutrophication is particularly well-documented for central European waters [e. g. 4, 9, 14, 18, 21, 22].

In the course of the past 15 years, the trophic state of most mesotrophic to eutrophic Swiss lakes has reached a plateau or, in some cases, has significantly decreased due to lake restoration efforts [1]. Within the context of this development, commonly referred to as oligotrophication, the question arises as to what extent the various fish species will react to the decreasing trophic state by altered growth rates. Changing growth rates, as well as year-class strength, will have an impact on the fishery and can be detected rather easily. Since cyprinid fish are not eaten by many Swiss consumers, the exploitation rate is generally low and unlikely to modulate growth rates noticeably. Roach (Rutilus rutilus (L.)), for instance, is quite common in most Swiss lakes, without building up very dense populations. Stunting has never been observed. Is was therefore considered a suitable species for evaluating the density independent effects of a changing environment on growth rates. 


\section{Description of site}

Lake Sarnen is a $7.64 \mathrm{~km}^{2}$ pre-alpine lake situated at an altitude of $469 \mathrm{~m}$ above sea level, $20 \mathrm{~km}$ SSW of Lucerne, central Switzerland. The lake drains into Lake Lucerne. Mean and maximum depths are $31.9 \mathrm{~m}$ and $52.0 \mathrm{~m}$, respectively. The mean residence time is 282 days. Lake temperature during the summer months regularly reaches $20-24{ }^{\circ} \mathrm{C}$ at the surface. The lake was polluted until 1981, mainly by domestic wastewater. Since then, a sewage pipeline collects most of the wastewater above and around the lake and brings it to a sewage treatment plant below the lake. Soil erosion does not seem to contribute much to eutrophication since the mountainous watershed of $267 \mathrm{~km}^{2}$ consists to a large part of rocks, forests, and weakly fertilized pastures. The development of trophic state will be discussed later.

The fish population of Lake Sarnen consists primarily of whitefish (Coregonus sp.) and roach. Bream (Abramis brama (L.)) and some other cyprinids, as well as perch (Perca fluviatilis (L.)), pike (Esox lucius (L.)), burbot (Lota lota (L.)) and eel (Anguilla anguilla (L.)) are less abundant. With an average total annual yield of $33.2 \mathrm{~kg} \mathrm{ha}^{-1}$ (1977-1984), Lake Sarnen ranks among the middle productive lakes [3]. The annual yield of cyprinid fish - of which more than $90 \%$ were roach - oscillated between 10.5 and $19.5 \mathrm{~kg} \mathrm{ha}^{-1}$ (mean $12.3 \mathrm{~kg} \mathrm{ha}^{-1}$ ) in the years 1972--1984. This indicates that population size, and thus density, was nearly constant throughout the period investigated, with the possible exception of $1978\left(15.2 \mathrm{~kg} \mathrm{ha}^{-1}\right)$ and $1979\left(19.5 \mathrm{~kg} \mathrm{ha}^{-1}\right)$. Cyprinid fish are exploited almost exclusively by the two commercial fishermen using gillnets.

\section{Methods}

Out of the 598 roach used in this study, 545 were caught with gill nets of 10 to $44 \mathrm{~mm}$ mesh size (bar) between February 1982 and Januray 1986. 53 fish, mainly age 0, 1 and 2 years, were caught between December 1983 and December 1984 with a midwater trawl similar to the one described by Gjernes [7]. The trawl is $14 \mathrm{~m}$ long, has a square mouth opening of 2.5 by $2.5 \mathrm{~m}$ and is operated at a speed of $1 \mathrm{~m} \mathrm{~s}^{-1}$ by a single boat powered by a $30 \mathrm{~kW}$ outboard motor. Mesh size (bar) decreases from $30 \mathrm{~mm}$ near the mouth to $5 \mathrm{~mm}$ in the cod end. Trawling depth is monitored by a pressure gauge attached to the upper (horizontal) spreader bar.

Ageing was done on scales following the procedures given by Mann [15], except that a binocular microscope with measuring eyepiece was used instead of a microprojector for measuring scales. Opercula from 30 fish only were used, mainly for double-checking scale readings on old fish. Fish lengths $L$ are natural tip lengths [20], with the caudal fin in its natural position. They can be converted into maximum total lengths $\mathrm{L}_{\max }$ by $\mathrm{L}_{\max }=1.00458 \mathrm{~L}(\mathrm{n}=248, \mathrm{r}=0.999)$.

Growth computations are based on the combined data for fish length from back-calculation and length recorded at the time of capture (annual growth completed). For back-calculation of lengths, a standard curve for the scala radius:length relationship had to be established. The length of individual fish at the end of each previous growing season was computed using the standard curve and applying an individual correction factor to account for the difference between the individual scale radius:Iength relationship and that of the standard curve. 


\section{Results and discussion}

\subsection{Age and average growth}

The length of the fish caught ranged between 41 and $343 \mathrm{~mm}$. Table 1 gives the age-composition and the year-class distribution of the fish captured. The scales of three fish had been lost.

Table 1. Age and year-class distribution of the 595 roach caught in Lake Sarnen.

\begin{tabular}{|c|c|c|c|c|c|c|c|c|c|c|c|c|c|c|c|c|}
\hline \multirow{2}{*}{$\begin{array}{l}\text { Year } \\
\text { class }\end{array}$} & \multicolumn{14}{|c|}{ Age (years) at capture } & \multirow[t]{2}{*}{ Total } & \multirow{2}{*}{$\begin{array}{c}\text { No. of } \\
\text { males }\end{array}$} \\
\hline & 0 & 1 & 2 & 3 & 4 & 5 & 6 & 7 & 8 & 9 & 10 & 11 & 12 & 17 & & \\
\hline 1966 & & & & & & & & & & & & & & 1 & 1 & 0 \\
\hline 1972 & & & & & & & & & & & 1 & & & & 1 & 0 \\
\hline 1973 & & & & & & & & & & 89 & 1 & & 1 & & 91 & 9 \\
\hline 1974 & & & & & & & & & 7 & & & 2 & & & 9 & 0 \\
\hline 1975 & & & & & & & & 2 & & & 4 & & & & 6 & 0 \\
\hline 1976 & & & & & & & 43 & & & 3 & & & & & 46 & 4 \\
\hline 1977 & & & & & & 10 & & & 8 & & & & & & 18 & 2 \\
\hline 1978 & & & & & 57 & & & 30 & 1 & & & & & & 88 & 25 \\
\hline 1979 & & & & 37 & & 1 & 62 & 2 & & & & & & & 102 & 32 \\
\hline 1980 & & & 14 & & 1 & 18 & 2 & & & & & & & & 35 & 12 \\
\hline 1981 & & 1 & & & 7 & 2 & & & & & & & & & 10 & 1 \\
\hline 1982 & & 4 & 7 & 2 & 20 & & & & & & & & & & 33 & 13 \\
\hline 1983 & 5 & 21 & 2 & 107 & & & & & & & & & & & 135 & 88 \\
\hline 1984 & 13 & & 7 & & & & & & & & & & & & 20 & 5 \\
\hline Total & 18 & 26 & 30 & 146 & 85 & 31 & 107 & 34 & 16 & 92 & 6 & 2 & 1 & 1 & 595 & 191 \\
\hline
\end{tabular}

As in other roach studies $[15,17]$, the line of best fit of the scale radius:length standard curve was found to be a parabola

$$
\mathbf{L}=\mathrm{a}+\mathrm{bS}+\mathrm{cS} \mathrm{S}^{2}
$$

where $\mathrm{L}=$ length $(\mathrm{mm}), \mathrm{S}=$ oral scale radius $\times 20(\mathrm{~mm})$, and the constants $\mathrm{a}=33.48$, $\mathrm{b}=3.20, \mathrm{c}=-0.0085(\mathrm{n}=571$, males and females combined).

Mean lengths and weights at each age, and instantaneous growth rate by weight are summarized in table 2 . Females grow significantly faster than males from the second year on ( $p<0.01$, t-test between mean lengths-at-age). In figure 1, the general growth curves of length for males and females are plotted, together with the Bertalanffy curves fitted to the data [20].

For calculating weight from length, the formula $W=a \cdot L^{b}$ was applied. The following constants were derived by least squares regression on the logarithmically transformed data:

$$
\begin{aligned}
& \text { males: } \quad \mathrm{a}=3.3150 \cdot 10^{-6} \quad \mathrm{~b}=3.2085 \quad \mathrm{~N}=164 \quad \mathrm{r}=0.997 \\
& \text { females: } \mathrm{a}=1.3976 \cdot 10^{-6} \quad \mathrm{~b}=3.3784 \quad \mathrm{~N}=385 \quad \mathrm{r}=0.998
\end{aligned}
$$

The constant $b$ indicates that females become heavier than males with increasing length. In table 2, the difference in ponderal growth is illustrated by the instantaneous growth rate $\mathrm{G}$, which decreases faster in males than in females. 
Table 2. Mean growth in length $(\mathrm{mm})$ and weight $(\mathrm{g})$, and instantaneous growth rate $\mathrm{G}$ of male and female roach.

\begin{tabular}{llccccccc}
\hline $\begin{array}{l}\text { Age } \\
\text { (years) }\end{array}$ & $\begin{array}{l}\text { No. of } \\
\text { fish }\end{array}$ & L (mm) & w (g) & G & $\begin{array}{l}\text { No. of } \\
\text { fish }\end{array}$ & L (mm) & w (g) & G \\
\hline 1 & 389 & 69 & 2.50 & 1.50 & 167 & 67 & 2.60 & 1.37 \\
2 & 388 & 107 & 11.2 & 1.00 & 166 & 103 & 10.2 & 0.90 \\
3 & 377 & 146 & 30.4 & 0.87 & 156 & 138 & 25.1 & 0.70 \\
4 & 324 & 189 & 72 & 0.53 & 86 & 172 & 51 & 0.51 \\
5 & 277 & 223 & 123 & 0.33 & 70 & 202 & 84 & 0.29 \\
6 & 216 & 246 & 171 & 0.30 & 49 & 222 & 113 & 0.22 \\
7 & 141 & 269 & 231 & 0.20 & 22 & 237 & 140 & 0.23 \\
8 & 107 & 286 & 282 & 0.09 & 12 & 254 & 176 & 0.06 \\
9 & 96 & 294 & 308 & 0.12 & 10 & 259 & 187 & - \\
10 & 33 & 305 & 348 & 0.02 & - & - & - & - \\
11 & 4 & 307 & 355 & 0.11 & - & - & - & - \\
12 & 2 & 317 & 396 & & - & - & - & \\
\hline
\end{tabular}

\section{LENGTH $(\mathrm{mm})$}

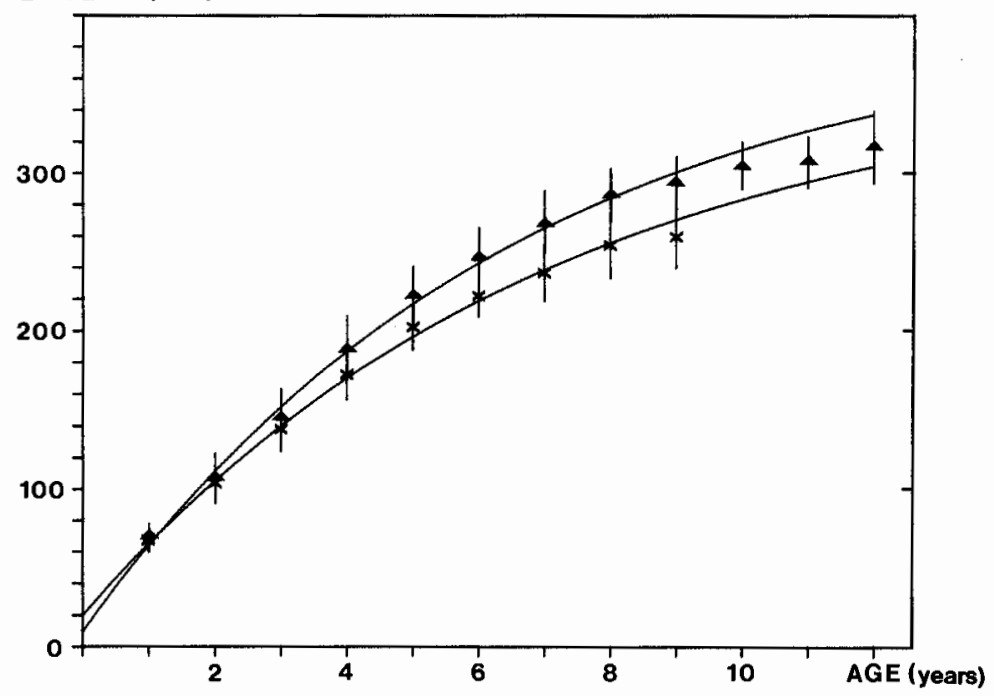

Figure 1. Average growth curves for male $(\times)$ and female ( 4 ) roach in Lake Sarnen. Mean values with $95 \%$ confidence limits (vertical bars). The models are Bertalanffy growth curves with the constants:

$$
\begin{aligned}
\text { males: } L_{\infty}=368.7 \mathrm{~mm}, \mathrm{~K}=0.142, \mathrm{t}_{0}=-0.387, \\
\text { females: } L_{\infty}=401.9 \mathrm{~mm}, \mathrm{~K}=0.150, \mathrm{t}_{0}=-0.157 \text {. }
\end{aligned}
$$


Out of the 556 fish which could be sexed, 191 (34.4\%) were males. Moreover, the proportion of males in the different year-classes varied considerably $(0-65.2 \%)$. Therefore, for the sake of homogeneity, all consecutive computations were based on the more abundant females only.

\subsection{Growth rate and trophic state}

Although data on the development of the trophic state of Lake Sarnen are rather sparse, a general trend can be observed using total phosphorus concentrations during spring overturn (fig. 2). Until about 1980, phosphorus concentrations increased up to some 20 $\mathrm{mg} \mathrm{m}^{-3}$. After reducing the sewage input, phosphorus values declined to less than half the peak value by early 1986 . Annual primary production increased from $82 \mathrm{~g} \mathrm{C} \mathrm{m}^{-2}$ in 1972 to $154 \mathrm{~g} \mathrm{C} \mathrm{m}^{-2}$ in 1980 . For the period after 1980 , no production values are available. According to current definitions [1, 6], Lake Sarnen is classified as oligotrophic, with a period of mesotrophy between about 1977 and 1981. Thus, the lake has reacted to the lower nutrient input within a remarkably short time.

The effect of changing lake trophic state on growth of roach can best be assessed by looking at figure 3. Although the annual growth increments vary considerably from year to year, the mean growth rates for the periods of oligotrophy and mesotrophy envisaged are similar. Partly significant negative correlations between phosphorus concentration and growth rate are the result of the cold summers of 1980 and 1981 (see below), at the time of maximum phosphorus concentration. Any correlation between total phosphorus concentration (from fig. 2) and 3 year moving average of annual growth increments (to

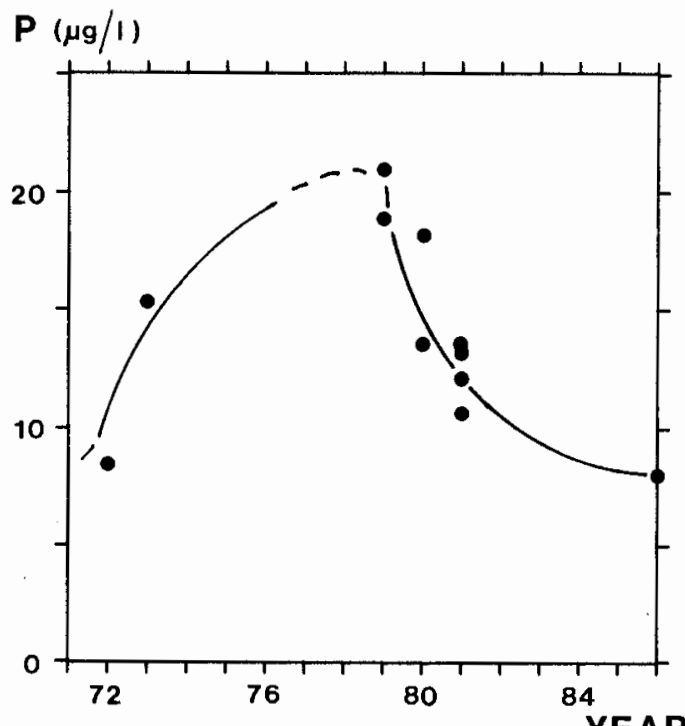

Figure 2. Total phosphorus concentration during spring overturn in Lake Sarnen, 1972-1986. Trends are indicated by hand-fitted lines. 
LENGTH INCR, (mm)

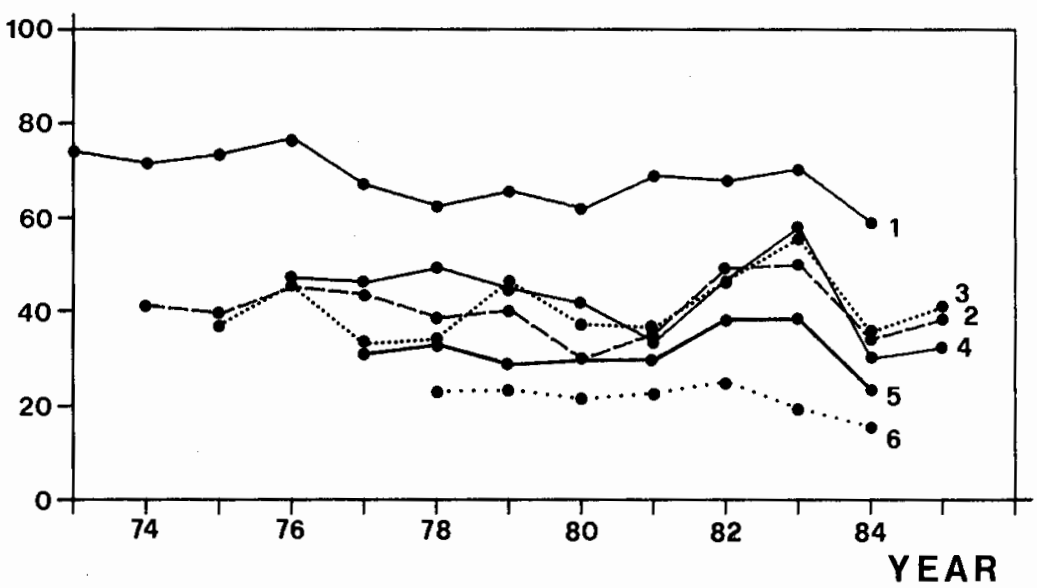

Figure 3. Annual length increments (mm) of female roach for the first to sixth year of life, years 1973-1985.

reduce temperature effects) yielded correlation coefficients which were far from significant for the assumed positive link. The closest positive relationship was with fourth year increments $(r=0.463, p=0.75)$, accounting for $21.4 \%$ of the variation only. Three points have to be mentioned here. First, total phosphorus concentration is a rather indirect measure for trophic state and should be replaced, where available, by production. Second, the time period of 12 years is rather short to bring forth subtle differences in growth rate which are related to trophic state. This is particularly true for our case where there is not a linear increase or decrease of lake trophy, but an up and down movement. Third, trophic state does have its effect on growth rates of roach: Roach in lakes of different trophic state but under otherwise similar conditions grow at different rates (e.g. $[4,12,17]$ and this study). However, growth rates of roach in lakes undergoing oligotrophication have not been published so far, and those of other species are obscured by high fishing pressure [10]. It is therefore concluded that more time will have to pass until the effect of lake oligotrophication can be expected to show up in the growth rate of roach. We intend to continue this study and to re-assess the situation in a later paper.

\subsection{Growth rate and temperature}

The pronounced year-to-year variation of the annual growth increments for the first to the sixth year, as shown in figure 3, suggests a strong influence of annually changing climatic factors such as, e. g., temperature [5]. Indeed, warm summers like those of 1976, 1979 , or 1983 are associated with elevated growth rates, while particularly cold summers like in 1980 result in reduced growth rates. Therefore, a more detailed analysis of the temperature effects on growth rates of roach was performed.

Since temperature data from Lake Sarnen were not available for the whole time period covered by the data on fish growth, temperature recordings from the effluent of Lake 
Lucerne, $23 \mathrm{~km}$ below Lake Sarnen, were used [13]. Temperature, expressed as the sum of degree-days above $12,13,14,15$, and $16^{\circ} \mathrm{C}$ for individual months and for all combinations of adjacent months from June to October was correlated with either the annual growth increments or separate age groups as in figure 3 , or with the composite annual growth up to age 6 from figure 4. Kempe [12] and Mann [15] signal $12^{\circ} \mathrm{C}$ as the lower temperature limit of growth in adult roach.

Optimum correlations between temperature and growth were found with day-degrees over $13^{\circ} \mathrm{C}$. Applying $12^{\circ} \mathrm{C}$ as the temperature limit yielded almost identical correlation coefficients, while those with 14,15 , and $16^{\circ} \mathrm{C}$ were progressively inferior. Table 3 summarizes the correlation coefficients between temperature and growth. There is a significant positive correlation between most combinations of summer months and the first three growth increments, or the composite length of up to four growing seasons. Consistently good correlations were obtained with the growth increments of the third year, and with the composite length of three year old fish. Cragg-Hine and Jones [5] and Ponton [19] note that a prolonged growing season due to a warm autumn contributes significantly to good annual growth. This view was substantiated by our data: The closest single relation was between degree-days over $12^{\circ} \mathrm{C}$ in August to October $(\mathrm{T})$ and third year increment $\left(\Delta \mathrm{L}_{3}\right)$ (fig. 5). The linear function applied was

$$
\Delta \mathrm{L}_{3}=4.15+0.107 \mathrm{~T} \quad(\mathrm{n}=10)
$$

where $r=0.945$ and $p<0.001$ accounting for $89.3 \%$ of the variation. Slightly inferior, but still highly significant, correlations were found between the temperature sum of the whole growing season from June to October and growth, thus illustrating the effect of temperature as the key factor responsible for the annual fluctuations of the growth rate. Growth during the first year of life did not prove to be a particularly sensitive indicator for temperature effects on growth (table 3). The most probable explanation for this phenomenon lies in the complex processes underlying the generation of a new year-class, namely oogenesis, pre- and postlarval development, food production, and predation. The processes themselves depend on environmental temperature and determine year-class strength. Year-class strength correlates to some degree with temperature in June-July

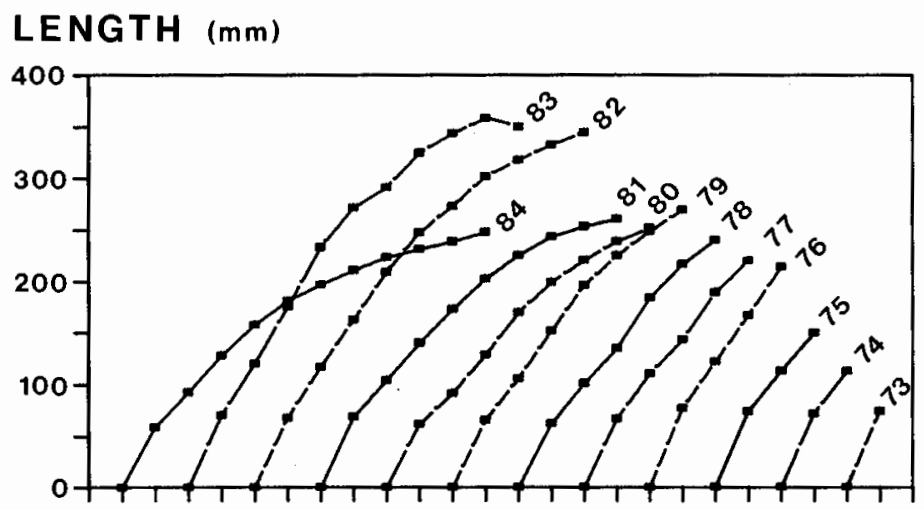

Figure 4. Composite annual growth curves of female roach within calendar years 1973-1984. Ordinate: length $(\mathrm{mm})$; abscissa: relative time scale in years. 
Table 3. Correlation coefficients between water temperature (degree-days over $13^{\circ} \mathrm{C}$ ) in different months, and growth given as annual lenght ( $\mathrm{mm}$ ) increments (left) and composite growth (mm) per calendar year (right). Females of year classes 1973-1984. For months, $6=$ June, $7=$ July, etc. ${ }^{*}$ significant at $\mathrm{p}<0.05$, ${ }^{* *}$ at $\mathrm{p}<0.01$.

\begin{tabular}{llllllllll}
\hline Months & \multicolumn{3}{l}{ Length } & \multicolumn{3}{c}{ increment in $\mathrm{n}^{\text {th }}$ year of life } & \multicolumn{4}{c}{ Composite growth after n growing seasons } \\
& l. & 2. & 3. & 4. & 5. & 2 & 3 & 4 & 5 \\
\hline 6 & $0.62^{*}$ & $0.61^{*}$ & 0.60 & 0.27 & 0.57 & $0.71^{*}$ & $0.73^{*}$ & 0.65 & 0.69 \\
7 & 0.54 & $0.77^{* *}$ & $0.65^{*}$ & 0.42 & 0.42 & $0.75^{* *}$ & $0.79^{* *}$ & $0.73^{*}$ & 0.66 \\
8 & $0.59^{*}$ & $0.61^{*}$ & $0.85^{* *}$ & 0.28 & 0.35 & $0.64^{*}$ & $0.79^{* *}$ & $0.68^{*}$ & 0.60 \\
9 & 0.31 & 0.28 & $0.67^{*}$ & 0.12 & 0.43 & 0.26 & 0.46 & 0.37 & 0.48 \\
10 & 0.38 & $0.62^{*}$ & $0.85^{* *}$ & 0.66 & 0.55 & $0.62^{*}$ & $0.81^{* *}$ & $0.83^{* *}$ & $0.78^{*}$ \\
6,7 & $0.59^{*}$ & $0.75^{* *}$ & $0.66^{*}$ & 0.38 & 0.49 & $0.77^{* *}$ & $0.80^{* *}$ & $0.74^{*}$ & $0.72^{*}$ \\
7,8 & $0.59^{*}$ & $0.76^{* *}$ & $0.74^{*}$ & 0.39 & 0.41 & $0.75^{* *}$ & $0.82^{* *}$ & $0.74^{*}$ & 0.67 \\
8,9 & 0.51 & 0.54 & $0.88^{* *}$ & 0.24 & 0.43 & 0.54 & $0.74^{*}$ & 0.62 & 0.60 \\
9,10 & 0.44 & 0.53 & $0.93^{* *}$ & 0.44 & 0.56 & 0.51 & $0.75^{*}$ & $0.69^{*}$ & 0.69 \\
$6-8$ & $0.63^{*}$ & $0.75^{* *}$ & $0.73^{*}$ & 0.37 & 0.46 & $0.77^{* *}$ & $0.83^{* *}$ & $0.75^{*}$ & 0.70 \\
$7-9$ & $0.61^{*}$ & $0.76^{* *}$ & $0.84^{* *}$ & 0.39 & 0.47 & $0.76^{* *}$ & $0.87^{* *}$ & $0.77^{*}$ & $0.71^{*}$ \\
$8-10$ & 0.55 & $0.61^{*}$ & $0.94^{* *}$ & 0.37 & 0.48 & $0.61^{*}$ & $0.81^{* *}$ & $0.72^{*}$ & 0.68 \\
$6-9$ & $0.64^{*}$ & $0.75^{* *}$ & $0.81^{* *}$ & 0.37 & 0.50 & $0.78^{* *}$ & $0.87^{* *}$ & $0.78^{*}$ & $0.72^{*}$ \\
$7-10$ & $0.60^{*}$ & $0.76^{* *}$ & $0.86^{* *}$ & 0.43 & 0.43 & $0.76^{* *}$ & $0.88^{* *}$ & $0.80^{*}$ & $0.73^{*}$ \\
$6-10$ & $0.63^{*}$ & $0.76^{* *}$ & $0.83^{* *}$ & 0.41 & 0.52 & $0.78^{* *}$ & $0.88^{* *}$ & $0.80^{*}$ & $0.75^{*}$ \\
\hline
\end{tabular}

[16], while annual 0+ growth seems to be related mainly to temperature in June, July and August. Strong (or weak) year-classes may or may not encounter favourable climatic conditions in the second half of summer. In the case of strong-year-classes, however, food tends be in short supply in the dense shoals of age 0 and 1 fish that populate the littoral zone. This leads to reduced growth rates, in spite of a warm autumn. Older roach, on the other hand, are usually more dispersed and more versatile in their feeding habits than $0+$

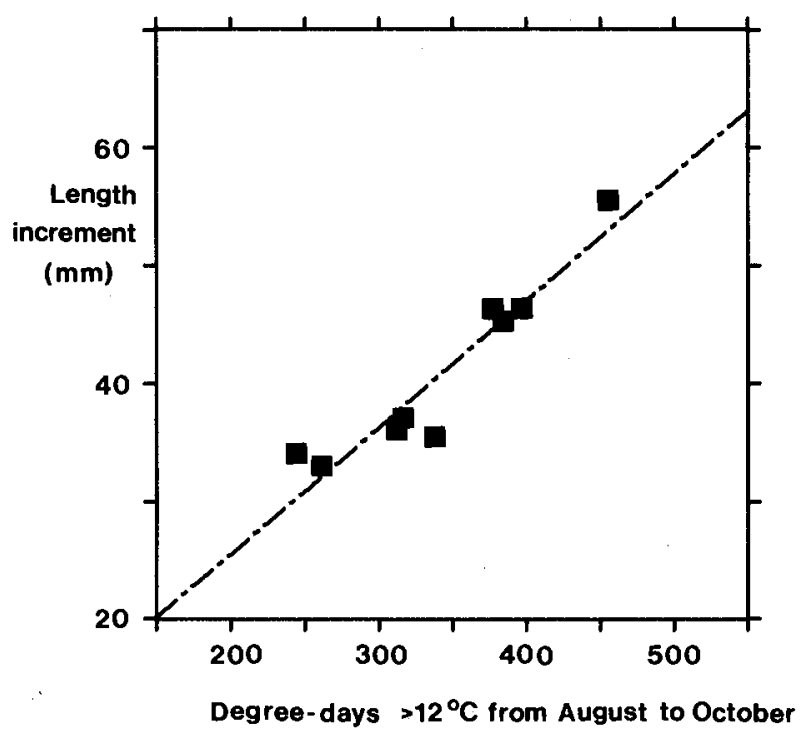

Figure 5. Plot of third year length increment versus water temperature sum expressed as degree-days over $12^{\circ} \mathrm{C}$ for August to October. The regression line fits the model described in the text. 
and $1+$ fish [12] which enables them to utilize the best food resource available, including pelagic and benthic food. This results in more regular growth rates, depending principally on temperature. The possibility that fish density in large shoals could act as growth depressor in lakes where average fish density is low was also pointed out by Ponton [19] for Lake Geneva.

Although year-class strength of the Lake Sarnen roach was not computed in this study, the figures in table 1 point to strong year-classes of 1973 and 1976, beside others. It is interesting to note that roach and other cyprinid fish like dace (Leuciscus leuciscus (L.)), chub (Leuciscus cephalus (L.)), and gudgeon (Gobio gobio (L.)) in Great Britain also formed strong year-classes in these years (summarized by [16]). Thus, it seems that the climatic factors governing year-class strength, and probably growth rate as well, are of a large-scale continental nature, acting in the same direction at least in northern and central Europe.

It is sometimes noted that years with good fish growth and strong year-classes are also good vintage years [8]. To test the validity of this general rule, the sugar content of grape juice in degrees Oechsle $\left({ }^{\circ} \mathrm{Oe}\right)$ from different grape types growing around Lake Zürich was plotted against the growth rates given in figures 3 und 4. A positive correlation reaching significance at $p<0.05$ was obtained using the particularly temperature-sensitive 'Räuschling' grape from Horgen. All other grape types gave positive, though not significant correlations. Figure 6 demonstrates the remarkable relation between this parameter used for integrating climatic factors [2], and fish growth some $50 \mathrm{~km}$ apart.

Summing up the findings presented, the changing trophic state of Lake Sarnen has not affected growth of roach noticeably so far. Temperature, on the other hand, is identified as the key factor governing the year-to-year fluctuations of the growth rate, obscuring any subtle trophic-related changes in growth within the time period sampled. In the long

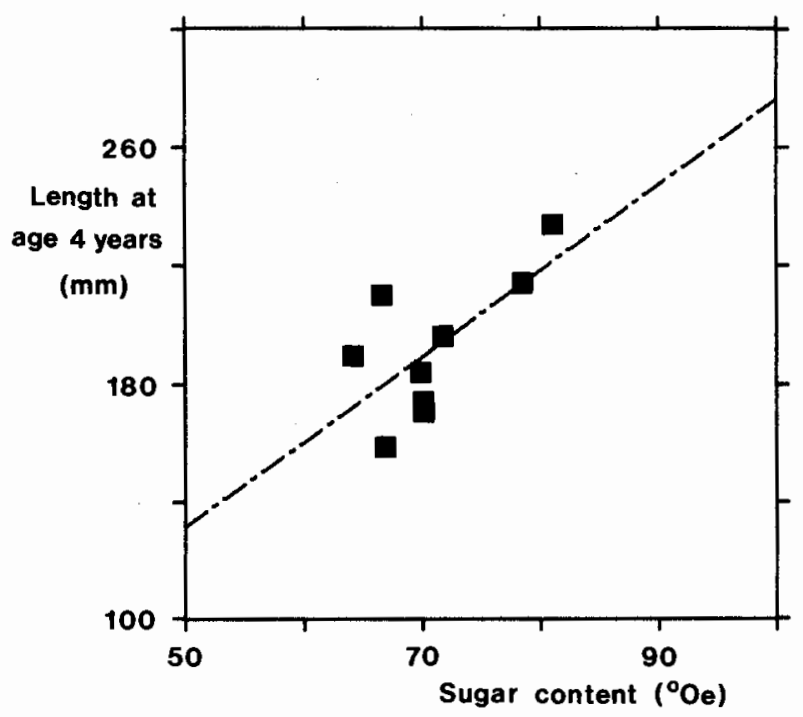

Figure 6. Plot of composite length after four years $L_{4}$ against sugar content $z$ of 'Räuschling' grapes from Horgen, Lake Zürich. The regression line fits the equation $L_{4}=-13.09+2.89 \mathrm{z}$. 
run, however, oligotrophication can be expected to moderately reduce the growth rate of roach in this lake.

\section{ACKNOWLEDGMENTS}

We thank J. Britschgi, A. and L. Amstalden, Wilen, for their kind cooperation in sampling the fish. P. Bossard, EAWAG, and the Laboratorium der Urkantone, Brunnen, provided some limnological data on Lake Sarnen. P. Basler, Wädenswil, supplied the wine vintage data.

\section{REFERENCES}

1 Ambühl, H.: Eutrophierungskontrollmassnahmen an Schweizer Mittellandseen. Z. Wass.- Abwass.-Forsch. $15,113-120(1982)$.

2 Basler, P.: Beeinflussung von Leistungsmerkmalen der Weinrebe (Vitis vinifera L.) in der Ostschweiz durch Klimafaktoren und Erträge sowie Versuch einer Qualitätsprognose. Wein-Wiss. 35, 1-80 (1980).

3 Barthelmes, D.: Hydrobiologische Grundlagen der Binnenfischerei (252 p.). VEB G.-Fischer-Verlag, Jena 1981.

4 Brenner, T.: Die Auswirkung der Eutrophierung des Bodensees auf Nahrung und Wachstum der Plötze (Rutilus rutilus). Fischwirt 23, 98-99 (1973).

5 Cragg-Hine, D., and Jones, J.W.: The growth of dace Leuciscus leuciscus (L.), roach Rutilus rutilus (L.) and chub Squalius cephalus (L.), in Willow Brook, Northamptonshire. J. Fish Biol. 1, 59-82 (1969).

6 Fricker, Hj. (comp.): OECD Eutrophication Programme, Regional Project Alpine Lakes (234 p.). OECD and Swiss Fed. Board for Envir. Prot. (Bundesamt f. Umweltschutz), Bern 1980.

7 Gjernes, T.: A portable midwater trawling system for use in remote lakes (13 p.). Fish. Envir. Canada, Fish. Mar. Serv. Tech. Rep. 888 (1979).

8 Hartmann, J.: Jahrgangsstärke von Fischen und Sommertemperatur. Fischwirt 27, 74-75 (1977).

9 Hartmann, J.: Fischwachstum bei Oligo-, Meso- und Eutrophie des Bodensees. Schweiz. Z. Hydrol. 40, 32-39 (1978).

10 Hartmann, J.: Der Fisch als Anzeiger einer Nährstoffabnahme im See? Öst. Fisch. 39, 101-104 (1986).

11 Healey, M.: Growth and recruitment in experimentally exploited lake whitefish (Coregonus clupeaformis) populations. Can. J. Fish. Aquat. Sci. 37, 255-267 (1980).

12 Kempe, O.: The growth of roach (Leuciscus rutilus L.) in some Swedish lakes. Rep. Inst. Freshwat. Res. Drottningholm 44, 42-104 (1962).

13 Landeshydrologie: Wassertemperaturen Reuss Luzern. Bundesamt für Umweltschutz/Landeshydrologie, Bern 1973-1984.

14 Lang, B., and Lang, C.: Effets combinés de la pêche et de l'eutrophisation sur la perche (Perca fluviatilis L.) dans les eaux vaudoises du Léman. Schweiz. Z. Hydrol. 45, 480-494 (1983).

15 Mann, R.H.K.: Observations on the age, growth, reproduction and food of the roach Rutilus rutilus (L.) in two rivers in southern England. J. Fish Biol. 5, 707-736 (1973).

16 Mills, C.A., and Mann, R.H.K.: Environmentally-induced fluctuations in year-class strength and their implications for management. J. Fish Biol. 27, suppl. A, 209-226 (1985).

17 Müller, R.: Das Weissfischproblem im Alpnacher See. Fischwirt 33, 37-39 (1983).

18 Nümann, W.: The Bodensee: effects of exploitation and eutrophication on the salmonid community. J. Fish. Res. Bd Canada 29, 833-847 (1972).

19 Ponton, D.: Croissance et alimentation de deux poissons planctonophages du Lac Léman: le corégone (Coregonus schinzi palea, Jurine) et le gardon (Rutilus rutilus L.) (168 p.). Thèse, Université Claude Bernard, Lyon I (1986).

20 Ricker, W.E.: Growth rates and models. In: Hoar, W.W., Randall, D.J., and Brett, J.R. (ed.): Fish Physiology 8, 677-743. Academic Press, New York 1979.

21 Rufli, H.: Ernährung und Wachstum der Felchenpopulationen (Coregonus spp.) des Thuner- und Bielersees. Schweiz. Z. Hydrol. 41, 64-93 (1979).

22 Svarvar, P.O., and Müller, R.: Die Felchen des Alpnachersees. Schweiz. Z. Hydrol. 44, 295-314 (1982).

Address of the authors: Lake Research Laboratory/EAWAG, CH-6047 Kastanienbaum, Switzerland. 